\author{
Paweł Bartoszczuk ${ }^{*}$ \\ Szkoła Główna Handlowa
}

\title{
BARIERY EKOINNOWACJI W PRZEDSIĘBIORSTWACH
}

\section{STRESZCZENIE}

W artykule omówiono definicje, podział i bariery ekoinnowacji. Jest to pojęcie trudne do zdefiniowania i trwają wciąż dyskusje, na ile definicja innowacji może być zastosowana do ekoinnowacji. Skutkiem proekologicznych działań jest nie tylko poprawa jakości środowiska, ale równoczesne obniżenie kosztów funkcjonowania przedsiębiorstwa, np. zmniejszenie wymierzanych kar czy opłat za zanieczyszczanie środowiska. $\mathrm{Na}$ podstawie danych z fundacji Gallupa oceniono wpływ różnych barier na wprowadzenie ekoinnowacji produktowych, procesowych i organizacyjnych w przedsiębiorstwach europejskich.

Słowa kluczowe: ekoinnowacje organizacyjne, produktowe, procesowe, przedsiębiorstwo

\section{Wprowadzenie}

Problem badawczy dotyczący ekoinnowacji, a szczególnie wpływu barier na ich wprowadzanie, jest dotychczas słabo rozpoznany. Problem ten jest aktualny, istotny dla europejskich przedsiębiorstw, polskiej gospodarki i preferowany przez UE. Celem pracy jest wskazanie istotnych barier hamujących wprowadzanie ekoinnowacji w przedsiębiorstwach. Przewiduje się, że niedługo gospodarka

\footnotetext{
*Adres e-mail: pbarto1@sgh.waw.pl.
} 
światowa stanie wobec poważnych wyzwań i granic wzrostu ze względu na dostępność zasobów naturalnych. Przystosowanie do nowej sytuacji wymagać będzie nowych rozwiązań, głównie ekoinnowacji. Takie rozwiązania mogą korzystnie wpłynąć na tworzenie miejsc pracy, a także stymulować wzrost gospodarczy. Ekoinnowacje są bardzo trudne do zdefiniowania, podobnie jak tradycyjne innowacje, i wciąż nie ma ścisłych kryteriów ani teorii wyjaśniających ich istotę. Obecnie tocząca się debata w literaturze światowej ${ }^{1}$ dotyczy problemu, w jakim stopniu ekoinnowacje są rodzajem działalności innowacyjnej, która potrzebuje własnej teorii i zupełnie innego podejścia ${ }^{2}$. Argumentuje się, że teoria innowacji ekologicznych może korzystać z ogólnej teorii innowacji, jednak ogólna teoria innowacji nie wyjaśnia złożonego charakteru ekoinnowacji oraz czynników im sprzyjających $^{3}$. W związku z tym szeroko omawiany jest problem, czy i w jakim stopniu dopuszczalne jest przeniesienie istniejących teorii innowacji do innowacji ekologicznych ${ }^{4}$, a szczególnie czy bariery dla firm wprowadzających ekoinnowacje są takie same, jak dla firm wprowadzających ogólne innowacje. Innowacje są przedmiotem zainteresowania wielu dyscyplin naukowych od nauk technicznych poprzez ekonomiczne, społeczne do nauk o zarządzaniu. W niniejszym artykule podjęto próbę zbadania istotności poszczególnych barier na wprowadzanie ekoinnowacji w przedsiębiorstwach europejskich. W tym celu zastosowano metodę regresji wielorakiej krokowej.

\section{Specyfika i rodzaje ekoinnowacji}

Ekoinnowacje stanowią innowacje mające korzystny wpływ na środowisko przyrodnicze. Jednym z kryteriów w klasyfikacji innowacji jest stosunek do środowiska przyrodniczego. Podział innowacji w zależności od niektórych przyjętych kryteriów obrazuje tabela 1 .

${ }^{1}$ S. Jakobsen, T. Clausen, Comparing the Innovation Process in Environmental and Non-Environmental Firms: A Look at Barriers to Innovation, DRUID Society Conference, Copenhagen 2014, s. $1-25$.

${ }^{2}$ V. De Marchi, Environmental innovation and $R \& D$ Cooperation: Empirical Evidence from Spanish Manufacturing Firms, „Research Policy” 2012, no. 41, s. 614-623.

3 Tamże.

${ }^{4} \mathrm{~K}$. Rennings, Redefining Innovation - Eco-Innovation Research and the Contribution from Ecological Economics, „Ecological Economics” 2000, no. 32, s. 319-332. 
Tabela 1. Podział innowacji ogółem według wybranych kryteriów

\begin{tabular}{|c|l|l|}
\hline Kryterium & Rodzaj innowacji & \multicolumn{1}{c|}{ Opis } \\
\hline \multirow{4}{*}{ Obiekt } & Produktowe & Nowy produkt, produkt zmodernizowany \\
\cline { 2 - 3 } & Technologiczne & $\begin{array}{l}\text { Całkowita lub częściowa zmiana czynników lub właściwości } \\
\text { procesów wytwórczych i proporcji między nimi }\end{array}$ \\
\cline { 2 - 3 } & Organizacyjne & $\begin{array}{l}\text { Zmiana systemów organizacyjnych, np. lean management, } \\
\text { kaizen, reengineering, zarządzanie jakością }\end{array}$ \\
\cline { 2 - 3 } & Społeczne & Zmiana systemów motywacyjnych, kultury organizacyjnej \\
\cline { 2 - 3 } $\begin{array}{c}\text { Stosunek } \\
\text { do środowiska } \\
\text { przyrodniczego }\end{array}$ & Marketingowe & Zmiana koncepcji i technik marketingowych \\
\cline { 2 - 3 } & $\begin{array}{l}\text { Proekologiczne } \\
\text { (ekoinnowacje) }\end{array}$ & $\begin{array}{l}\text { Prowadzą do oszczędności zużycia materiałów; wprowadza- } \\
\text { nie na rynek produktów ekologicznych }\end{array}$ \\
\cline { 2 - 3 } & $\begin{array}{l}\text { Oównowąage } \\
\text { ekologiczną }\end{array}$ & $\begin{array}{l}\text { Obojętne dla środowiska przyrodniczego i człowieka } \\
\text { rodniczego i człowieka }\end{array}$ \\
\hline \multirow{2}{*}{} &
\end{tabular}

Źródło: opracowanie na podstawie: L. Białoń, Zarzadzanie działalnościa innowacyjna, Placet, Warszawa 2010, s. 21-24.

Bardzo ważne jest kryterium stosunek do środowiska przyrodniczego, zgodnie z którym można wyodrębnić ekoinnowacje ${ }^{5}$.

Ekoinnowacje należy rozpatrywać przynajmniej z trzech perspektyw:

a) poszczególnych organizacji i przedsiębiorstw sfery produkcyjnej, a także sfery usług;

b) układów przestrzennych (gmin, miast, województw, regionów różnej wielkości, aż po skalę globalną);

c) konsumentów (indywidualnych i instytucjonalnych).

Powszechnie uznaje się, że ekoinnowacje zmierzają do rozwoju nowych produktów i procesów, które dostarczają konsumentowi i biznesowi nie tylko korzyści, ale istotnie zmniejszają negatywne oddziaływanie środowiskowe ${ }^{6}$. Claude Fussler i Peter James $^{7}$ definiują ekoinnowacje jako nowe produkty i procesy, które dostarczają biznesowi i klientom wartości ze znacznym zmniejszeniem oddziaływania na środowisko.

${ }^{5}$ W. Janasz, Innowacje i ich miejsce $w$ tworzeniu wartości przedsiębiorstwa, w: Innowacje w dziatalności przedsiębiorstw w integracji z Uniq Europejska, red. W. Janasz, Difin, Warszawa 2005, s. 40.

${ }^{6}$ B. Ziółkowski, Znaczenie ekoinnowacji dla rozwoju przedsiębiorstw, w: Zrównoważony rozwój w teorii ekonomii $i$ w praktyce, red. A. Graczyk, Wydawnictwo Akademii Ekonomicznej we Wrocławiu, Wrocław 2008, s. 526-534.

${ }^{7}$ C. Fussler, T. James, Driving Eco-Innovation: A Beak through Discipline for Innovation and Sustainability, Pearson Education, London 1996. 
Ekoinnowacja to wdrożenie do powszechnego wykorzystania nowych produktów, technologii oraz urządzeń infrastruktury, których celem jest ochrona elementów środowiska: powietrza, wód, ziemi, krajobrazu, flory i fauny, a także człowieka przed negatywnym wpływem działalności gospodarczej ${ }^{8}$. W efekcie wdrożenie ekoinnowacji powinno prowadzić do zrównoważonego rozwoju.

Interesujące rozróżnienie ekoinnowacji i tradycyjnych innowacji zaproponowali René Kemp i Peter Pearson'. Otóż autorzy ci doszli do przekonania, że aby określić, czy innowacje mają charakter ekologiczny, należy wykazać, że w wyniku ich zastosowania negatywny wpływ na środowisko zmniejsza się w stosunku do efektów innego rozwiązania. Podobnie Jacquelyn Ottman ${ }^{10}$ trafnie stwierdza, że celem ekoinnowacji jest redukcja negatywnego oddziaływania przedsiębiorstwa na środowisko przyrodnicze.

Część problemów polegających na określeniu, co jest innowacją, wynika z względnego charakteru definicji innowacji. Przykładowo, użycie urządzeń kontroli zanieczyszczeń przez przedsiębiorstwo po raz pierwszy jest innowacją z punktu widzenia konkretnego przedsiębiorstwa, ale nie będzie już innowacją dla producenta urządzenia. Dla producenta innowacja to znacząca zmiana w urządzeniu zmniejszającym poziom zanieczyszczenia lub tworzenie nowych technologii. Kiedy mierzymy ekoinnowacje, należy wyjaśnić, czy mamy na myśli pomiar tworzenia innowacji lub pierwsze wdrożenie produktów, technologii, usług lub praktyk. Inne ważne rozróżnienie to takie, czy dana innowacja powoduje poprawę w przypadku, gdy dany produkt już istnieje lub jest to całkowicie nowy produkt.

Nowym terminem są zrównoważone innowacje, czyli nowe lub zmodyfikowane procesy, techniki, praktyki, systemy i produkty pozytywnie oddziałujące na środowisko, a ponadto gospodarkę i społeczeństwo ${ }^{11}$. Pewnym problemem może być stosowanie różnej terminologii, ponieważ oprócz ekoinnowacji używane są

${ }^{8}$ L. Białoń, Zarządzanie działalnościa innowacyjną, Placet, Warszawa 2010, s. 25.

9 R. Kemp, A. Pearson, Measuring Eco-Innovation, final report of MEI project for DG Research of the European Commission, Brussels 2008, s. 7.

10 J. Ottman, The New Rules of Green Marketing: Strategies, Tools, and Inspiration for Sustainable Branding, Greenleaf Publishing, Brussels 2011, s. 89.

${ }^{11}$ F. Steward, Opponent Note: Ecoinnovation - Enviromental Benefits, „Economic Growth and Job Creation" 2006, Green Roads to Growth, Proceedings of Expert and Policy Maker Forums, Kopenhaga, 1-2 marca, 2006 r., http://www.dors.dk/files/media/graphics/Synkron-Library/Publikationer/ IMV/2006/GG_version_6.pdf(23.08.2015). 
też nazwy: zielone technologie, technologie środowiskowe, technologie ekologiczne, ekotechnologie, innowacje ekologiczne i inne ${ }^{12}$. Ekoinnowacje, nazywane także zielonymi lub innowacjami środowiskowymi, stanowią szerokie pojęcie, które uwzględnia również „niezaplanowane innowacje ekologiczne”"13.

Definicje innowacji środowiskowych w odniesieniu do zawartości pokazują te same kwestie i mogą być stosowane zamiennie. Niemniej jednak zidentyfikowano sześć istotnych wymiarów ekoinnowacji w różnych definicjach:

Cel innowacji: produktowa, procesowa, nowa metoda marketingowa;

Orientacja rynkowa: zaspokojenie potrzeb/bycie konkurencyjnym na rynku;

Aspekt ochrony środowiska: zmniejszenie negatywnego wpływu (optymalna: zerowy);

Faza: uwzględniony pełny cykl życia produktu (dla zmniejszenia przepływów materiałów);

Impuls: zamiarem może być oszczędność i ekologia;

Poziom: ustanowienie nowego innowacyjnego/zielonego standardu dla firmy.

Pierwsze dwa aspekty występują prawie we wszystkich definicjach ekoinnowacji, stwierdzając, że celem ekoinnowacji może być sam produkt, proces lub nowa metoda marketingowa (np. model biznesowy) oraz że ekoinnowacje powinny zaspokoić potrzeby użytkownika lub rozwiązać konkretny problem i zapewnić konkurencyjność produktu na rynku ${ }^{14}$. Odnośnie do aspektu środowiskowego to wszystkie definicje zgodnie wskazują na to, że innowacyjność powinna przynosić zdecydowanie mniejszy negatywny wpływ na środowisko. Czwarty aspekt pojawia się tylko w dwóch definicjach, tj. Kempa i Pearsona ${ }^{15}$ oraz Alasdaira Reida i Michała Miedzińskiego ${ }^{16}$. Autorzy postulują pełną analizę cyklu życia produktu i wnikliwą analizę wszystkich czynników wejściowych i wyjściowych. Następny, piąty aspekt wiąże się z motywami redukcji

${ }^{12}$ B. Ziółkowski, Znaczenie ekoinnowacji.., s. 527.

${ }^{13}$ A. Arundel, R. Kemp, Measuring Eco-Innovation, United Nations University - Maastricht Economic and Social Research and Training Centre on Innovation and Technology, Maastricht 2009, s. 10.

${ }^{14}$ T. Schiederig, F. Tietze, C. Herstatt, Green Innovation in Technology and Innovation Management - an Exploratory Literature Review, „R \& D Management” 2012, no. 42, s. 180-192.

${ }^{15}$ R. Kemp, A. Pearson, Measuring Eco-Innovation...

${ }^{16}$ A. Reid, M. Miedziński, Eco-Innovation. Final Report for Sectoral Innovation Watch, Technopolis Group, 70 Report, Technopolis Group 2008, www.technopolis-group.com/resources/downloads/661_report_final.pdf(1.07.2015), s. 52. 
zanieczyszczeń, które mogą mieć charakter ekonomiczny lub ekologiczny (np. zmniejszenie zużycia materiałów). Ostatni aspekt dotyczy problemów związanych z definicją innowacji i bycia przyjaznym dla środowiska ze względu na to, że pojęcia te nie są precyzyjnie sformułowane (np. każda innowacja może być nowa w świecie, w branży albo w konkretnej firmie). Oznacza to, że pojęcia te są interpretowane jako ustanowienie nowego standardu zielonych innowacji na poziomie przedsiębiorstw ${ }^{17}$.

Szeroko dyskutowana jest kwestia, jakie bariery występują dla firm wprowadzających ekoinnowacje, a jakie dla firm wprowadzających ogólne innowacje. Istnieją różne podejścia do badania innowacji. Jednym z nich jest badanie charakteru, pochodzenia i znaczenia różnych barier innowacji, dlatego poniżej skupiono się na tych barierach.

\section{Bariery ekoinnowacji}

Problem dotyczący barier wprowadzania ekoinnowacji jest ważny dla polskich przedsiębiorstw, gospodarki i preferowany przez UE. W krótkoterminowej perspektywie Komisja Europejska ma zamiar interweniować w sektorach, które mają silny potencjał, aby wspomóc „zieloną gospodarkę”. Badania i innowacje są priorytetem w unijnej agendzie na rzecz wzrostu gospodarczego i zatrudnienia.

W porównaniu z państwami liderami pod względem barier wdrażania ekoinnowacji doświadczenia krajowych podmiotów gospodarczych nie były do tej pory w sposób wyczerpujący analizowane i opisane w literaturze. Twórcy raportu Drzemiacy tygrys, spętany orzet. Dylematy polskiej debaty o polityce innowacyjnej podkreślają, że obecny model wzrostu gospodarczego Polski wyczerpie się niedługo ${ }^{18}$. Sposobem przezwyciężenia może być wprowadzenie ekoinnowacji.

Ważną inicjatywą unijną poświęconą badaniom nad ekoinnowacjami jest obecnie Obserwatorium Ekoinnowacji ${ }^{19}$. Na podstawie tych wskaźników stworzony został ranking „Eco-Innovation Scoreboard”, w którym Polska zajęła jedno z ostatnich miejsc wśród wszystkich krajów UE-27.

17 T. Schiederigi, F. Tietze, C. Herstatt, Green Innovation..., s. 3.

${ }^{18}$ M. Bukowski, A. Szpor, A. Śniegocki, Drzemiacy tygrys, spętany orzet. Dylematy polskiej debaty o polityce innowacyjnej, Instytut Badań Strukturalnych, Warszawa 2012.

19 Ecoinnovation observatory, http://www.eco-innovation.eu/ (15.06.2015). 
Niestety, ekoinnowacje napotykają barierę braku zainteresowania polityków $\mathrm{w}$ wielu krajach, w tym w Polsce, co ogranicza wizje wykorzystania funduszy strukturalnych dla celów rozwojowych przez wprowadzanie ekoinnowacji. W konsekwencji polityka kładzie nacisk na likwidację opóźnień cywilizacyjnych, zapominając o przyszłych zmianach znaczenia sektorów gospodarki oraz barierach starego modelu wzrostu opartego na konkurowaniu ceną ${ }^{20}$. Ekoinnowacje wpływają na efektywność gospodarki poprzez wprowadzanie rozwiązań umożliwiających ograniczanie energochłonności procesów i redukujących zużycie materiałów na jednostkę produkcji.

Do najważniejszych barier ekoinnowacji zaliczamy wysokie koszty ich wprowadzenia. Po stronie technologicznej można wyróżnić następujące bariery ${ }^{21}$ :

a) dostępność technologii dla specyficznych zastosowań; możliwości wdrożenia technologii przy pewnych uwarunkowaniach oraz standardach projektowania procesów;

b) brak alternatywnych substancji w celu zastąpienia substancji niebezpiecznych;

c) wysoki stopień skomplikowania związany z zastosowaniem technologii unieszkodliwiania odpadów;

d) sceptycyzm w działaniu określonych technologii, a w związku z tym opór przed inwestowaniem.

\section{Do innych barier zaliczymy bariery finansowe:}

a) wysokie koszty finansowania $B+R$;

b) koszty związane z ryzykiem zmian procesów w stosunku do poziomu akceptacji klientów i jakości produktów;

c) brak kompleksowej analizy kosztów i korzyści, jak również kalkulacji kosztów;

d) brak zrozumienia i trudności w oszacowaniu przyszłych kosztów;

e) krótkookresowe kalkulacje zysków powodujące mniejszą akceptację dłuższych okresów zwrotu inwestycji sprzętowych.

Ponadto, możliwe jest wystąpienie zmniejszenia konkurencyjności danej firmy na rynku ze względu na brak podobnych inwestycji w innych przedsiębiorstwach,

${ }^{20}$ M. Bukowski, A. Szpor, A. Śniegocki, Drzemiacy tygrys..., s. 4-5; A. Kassenberg, A. Śniegocki, Rola ekoinnowacji w niskoemisyjnej transformacji, Instytut na rzecz Ekorozwoju, Warszawa 2011, http://www.ine-isd.org.pl/theme/UploadFiles/File/publikacje/raport_np2050.pdf (15.06.2015), s. 2.

${ }^{21}$ Methodological Report, Ecoinnovation Observatory 2012, http://www.eco-innovation.eu/index. php?option=com_content\&view=article \&id=25\&Itemid=211 (17.06.2015), s. 27 . 
np. technologie redukujące ilość odpadów. Dodatkowo, brak wystarczającej ilości kapitału stanowi duże ograniczenie dla firm. Ponadto, możliwe jest wystąpienie zmniejszenia konkurencyjności danej firmy, która inwestując $\mathrm{w}$ technologie ekoinnowacyjne, ponosi koszty, względem innych przedsiębiorstw, które nie podejmują podobnych inwestycji, np. technologie redukujące ilość odpadów. F.D. Angelo i współautorzy stwierdzili ${ }^{22}$, że ekoinnowatorzy napotykają na liczne bariery na poziomie zarówno makro, jak i mikro. Jak donoszą Robert Thompson i William Green ${ }^{23}$, niewystarczające wsparcie, czasochłonność oraz ograniczone zasoby stanowią istotne bariery ekoinnowacji.

\section{Wyniki badania empirycznego - przykład przedsiębiorstw europejskich}

$\mathrm{Z}$ uwagi na brak danych dla polskich przedsiębiorstw autor skorzystał z danych dla 27 przedsiębiorstw z UE zgromadzonych przez Instytut Gallupa ${ }^{24}$. W celu identyfikacji barier wpływających na innowacje ekologiczne użył modelu regresji wielorakiej. W różnych wariantach modelu poszczególne rodzaje ekoinnowacji uwzględnił on jako odsetek przedsiębiorstw, które wdrożyły poszczególne rodzaje ekoinnowacji w latach 2009-2010 (zmienna zależna). Zmiennymi niezależnymi były stosowane w modelach bariery mające wpływ na decyzje przedsiębiorstw, czy powinny one wprowadzić innowacje ekologiczne, czy też nie. Dla podanych obiektów przeprowadzonej przez autora analizy, czyli 27 grup przedsiębiorstw z krajów UE, wartości zmiennych niezależnych zostały obliczone jako średnie ważone, w których wagami były frakcje ankietowanych respondentów oceniających podane czynniki jako bardzo ważne i ważne. Wyróżniono ekoinnowacje produktowe, procesowe oraz organizacyjne, a ponadto zaprezentowano bariery wpływające na tego typu innowacje. W analizie autor wykorzystał model regresji krokowej wstecznej. W wyniku obliczeń zidentyfikował zmienne niezależne będące statystycznie istotnymi.

${ }^{22}$ F.D. Angelo, C.J.C. Jabbour, S.V. Galina, Environmental innovation: In Search of a Meaning, „World Journal of Entrepreneurship, Management and Sustainable Development” 2012, vol. 8 (2/3), s. $113-121$.

${ }^{23}$ R. Thompson, W. Green, When Sustainability is Not a Priority: An Analysis of Trends and Strategies, „International Journal of Sustainability in Higher Education” 2005, vol. 6 (1), s. 7-17.

${ }^{24}$ Gallup, Attitudes of European Entrepreneurs Towards Eco-Innovation. Analytical Report, Flash Eurobarometer 2011 , no. 315 , s. 27-40. 
Tabela 2. Wyniki modelu regresji wielorakiej

\begin{tabular}{|c|c|c|c|c|c|c|}
\hline \multirow[b]{2}{*}{ Zmienne niezależne } & \multicolumn{6}{|c|}{ Zmienne zależne } \\
\hline & $\begin{array}{l}\text { ekoinnowacje } \\
\text { produktowe }\end{array}$ & $\begin{array}{l}\text { SE- } \\
\text { błąd }\end{array}$ & $\begin{array}{c}\text { ekoinnowacje } \\
\text { procesowe }\end{array}$ & $\begin{array}{l}\text { SE- } \\
\text { błąd }\end{array}$ & $\begin{array}{l}\text { ekoinnowacje } \\
\text { organizacyjne }\end{array}$ & $\begin{array}{l}\text { SE- } \\
\text { błąd }\end{array}$ \\
\hline Stała & $11,18^{* *}$ & 3,75 & $22,6^{* *}$ & 4,06 & $-1,32$ & 6,24 \\
\hline $\begin{array}{l}\text { Ograniczony dostęp do wiedzy } \\
\text { i nowoczesnych technologii }\end{array}$ & $0,29 *$ & 0,08 & $0,36^{*}$ & 0,15 & & \\
\hline $\begin{array}{c}\text { Brak odpowiednich } \\
\text { partnerów biznesowych }\end{array}$ & & & $-0,24 *$ & 0,1 & $-0,31^{*}$ & 0,14 \\
\hline $\begin{array}{l}\text { Brak zewnętrznego } \\
\text { finansowania }\end{array}$ & & & & & $0,32 * *$ & 0,11 \\
\hline $\begin{array}{c}\text { Brak wykwalifikowanego } \\
\text { personelu }\end{array}$ & & & & & $0,32 *$ & 0,15 \\
\hline$R 2$ & 0,32 & & 0,22 & & 0,15 & \\
\hline$F(p$ wartość $)$ & $12,11(<0,001)$ & & $3,3(<0,05)$ & & $4,75(<0,01)$ & \\
\hline
\end{tabular}

Źródło: opracowanie własne na podstawie badań w ramach Projektu, który został sfinansowany ze środków Narodowego Centrum Nauki przyznanych na podstawie decyzji nr DEC-2013/11/B/HS4/02122).

Okazuje się, że na ekoinnowacje produktowe ma wpływ zmienna „ograniczony dostęp do wiedzy i nowoczesnych technologii”. Wbrew oczekiwaniom zmienna ta nie stanowiła bariery dla przedsiębiorstw we wprowadzaniu ekoinnowacji produktowych. Inne zmienne nie były statystycznie istotne. W przypadku ekoinnowacji procesowych zmiennymi istotnymi okazały się „brak odpowiednich partnerów biznesowych” oraz „ograniczony dostęp do wiedzy i nowoczesnych technologii”, ale oddziałują one w różnych kierunkach. O ile „brak odpowiednich partnerów biznesowych" nie sprzyja wprowadzeniu ekoinnowacji procesowych zgodnie z oczekiwaniami, to zmienna „ograniczony dostęp do wiedzy i nowoczesnych technologii” działa w przeciwnym kierunku, niezgodnie z intuicją. W przypadku ekoinnowacji organizacyjnych zmiennymi istotnymi okazały się „brak odpowiednich partnerów biznesowych”, a ponadto „brak finansowania zewnętrznego” oraz „brak odpowiedniego personelu”. Zmienna „brak odpowiednich partnerów biznesowych” jest statystycznie istotna i wpływa na zmniejszenie wprowadzania ekoinnowacji organizacyjnych. Pozostałe zmienne niezgodnie z oczekiwaniami nie stanowią bariery dla ekoinnowacji organizacyjnych. 
Z uwagi na brak danych dotyczących Polski wyniki obliczeń należy traktować jako przykład zastosowania metody badawczej. Dokładne obliczenia zostaną przeprowadzone po uzyskaniu danych z polskich przedsiębiorstw.

\section{Podsumowanie}

Do istotnych barier wprowadzania ekoinnowacji w przedsiębiorstwach europejskich zaliczamy brak środków finansowych, ograniczony dostęp do wiedzy oraz brak odpowiednio wykwalifikowanych pracowników. Pomimo tych barier polskie firmy mogą konkurować z czołówką europejską na wielu rynkach technologii ekoinnowacyjnych. W przeciwieństwie do najbardziej złożonych technologii energetycznych (elektrownie jądrowe) na polu energetyki odnawialnej (energetyka wiatrowa, biogazownie) i rozproszonej występują duże szanse na osiągnięcie sukcesu, biorąc pod uwagę zarówno wymagany potencjał, jak i wsparcie udzielane w tej chwili polskim innowatorom ze środków krajowych i unijnych.

Prowadzone obecnie działania proekologiczne w większości przedsiębiorstw są niewystarczające i ograniczają się do usuwania skutków zanieczyszczenia zamiast do stosowania czystszych technologii. Wydaje się, że obserwujemy obecnie w Polsce dwie charakterystyczne bariery ekoinnowacji. Z jednej strony słaby poziom rozwoju Polski niewystarczający, aby nastąpił zasadniczy wzrost zapotrzebowania na ekoinnowacje ze strony biznesu, a z drugiej strony nie przeznacza się istotnych środków finansowych, gdyż nie będą one wykorzystane. W celu głębszej analizy planowane jest przeprowadzenie badań ankietowych w polskich przedsiębiorstwach.

\section{Literatura}

Andersen M., Eco-Innovation - Towards a Taxonomy and a Theory, „25th Celebration DRUID Conference 2008 on Entrepreneurship and Innovation - Organizations, Institutions, Systems and Regions", Copenhagen 2008.

Arundel A., Kemp R., Measuring Eco-Innovation, United Nations University - Maastricht Economic and Social Research and Training Centre on Innovation and Technology, Maastricht 2009.

Białoń L., Zarządzanie działalnościa innowacyjna, Placet, Warszawa 2010. 
Bukowski M., Szpor A., Śniegocki A., Drzemiacy tygrys, spętany orzet. Dylematy polskiej debaty o polityce innowacyjnej, Instytut Badań Strukturalnych, Warszawa 2012.

Marchi De V., Environmental Innovation and $R \& D$ Cooperation: Empirical Evidence from Spanish Manufacturing Firms, „Research Policy” 2012, no. 41.

Fussler C., James T., Driving Eco-Innovation: A Break through Discipline for Innovation and Sustainability, Pearson Education, London 1996.

Gallup, Attitudes of European Entrepreneurs Towards Eco-Innovation. Analytical Report, Flash Eurobarometer 2011, no. 315.

GUS, Działalność innowacyjna przedsiębiorstw 2006-2009, Warszawa 2009, http://www.stat. gov.pl/cps/rde/xbcr/gus/nts_dzialanosc_innowacyjna_2006-2009.pdf2009 (1.08.2015).

Janasz W., Innowacje $i$ ich miejsce $w$ tworzeniu wartości przedsiębiorstwa, w: Innowacje w działalności przedsiębiorstw w integracji z Unią Europejska, Difin, Warszawa 2005.

Kassenberg A., Kasseberg P., Ecoinnovation in Poland, Ecoinnovation Observatory, Country profile 2011.

Kassenberg A., Śniegocki A., Rola Ekoinnowacji w niskoemisyjnej transformacji, Instytut na rzecz Ekorozwoju, Warszawa 2011.

Kemp R., Pearson A., Measuring Eco-Innovation, final report of MEI project for DG Research of the European Commission, Brussels 2008.

Ottman J., The New Rules of Green Marketing: Strategies, Tools, and Inspiration for Sustainable Branding, Greenleaf Publishing, Brussels 2011.

Reid A., Miedziński M., Eco-Innovation. Final Report for Sectoral Innovation Watch, 70 Report, Technopolis Group 2008, www.technopolis-group.com/resources/ downloads/661_report_final.pdf.

Rennings K., Redefining Innovation - Eco-Innovation Research and the Contribution from Ecological Economics, „Ecological Economics” 2000, no. 32.

Schiederig T., Tietze F., Herstatt C., Green Innovation in Technology and Innovation mManagement - an Exploratory Literature Review, „R \& D Management”2012, no. 42.

Steward F., Opponent Note: Ecoinnovation - Enviromental Benefits, „Economic Growth and Job Creation" 2006, Green Roads to Growth, Proceedings of Expert and Policy Maker Forums, Kopenhaga, 1-2 marca, 2006 r., http:/www.dors.dk/files/media/graphics/ Synkron-Library/Publikationer/IMV/2006/GG_version_6.pdf.

Woźniak L., Trinks R., Bącal W., Ekoinnowacje - nowy paradygmat, odmienna gospodarka, proekologiczna świadomość przedsiębiorców, w: Przedsiębiorczość i innowacyjność matych $i$ średnich przedsiębiorstw - wyzwania współczesności, red. A. Kaleta, K. Moszkowicz, L. Woźniak, Wydawnictwo Akademii Ekonomicznej we Wrocławiu, Wrocław 2004.

Ziółkowski B., Znaczenie ekoinnowacji dla rozwoju przedsiębiorstw, w: Zrównoważony rozwój $w$ teorii ekonomii $i$ w praktyce, red. A. Graczyk, Wydawnictwo Akademii Ekonomicznej we Wrocławiu, Wrocław 2008. 


\title{
BARRIERS TO ECO-INNOVATION IN POLISH ENTERPRISES
}

\begin{abstract}
The article discusses the definition, classification and barriers of eco-innovation. This concept is difficult to define and still under discussion how the definition of innovation can be applied to eco-innovation. The effect of eco-innovation is not only improving the environment, but at the same time reducing the costs of the enterprise, eg.: reduction of penalties or fees for pollution. Based on data from Gallup foundation the impact of various factors on the introduction of eco-innovation of product, process and organization was analyzed.
\end{abstract}

Keywords: enterprise, organizational eco-innovation, product eco-innovation, process ecoinnovation, enterprise

JEL Codes: 030, Q56

Translated by Pawet Bartoszczuk 